\title{
TESTS OF SELECTED MECHANICAL PROPERTIES OF WELDED JOINTS IN ROTORCRAFT
}

\author{
Izabela Korzec $^{1^{*}}$ (D) 0000-0002-7984-5174 \\ Tomasz Lusiak $^{1}$ (D) 0000-0003-2324-4596 \\ Martin Bugaj $^{2}$ (D) 0000-0001-7205-855X \\ ${ }^{1}$ Lublin University of Technology, Nadbystrzycka 38 D, 20-618 Lublin, Poland \\ ${ }^{2}$ University of Zilina, Univerzitna 8215/1, 010-26 Zilina, Slovakia \\ * $\underline{\text { i.korzec@pollub.pl }}$
}

\begin{abstract}
The following article presents experimental use of different ways of inguinal connecting of aircraft elements using TIG (Tungsten Inert Gas), MAG (Metal Active Gas) and arched coated electrode. The object of the research were samples of rotorcraft elements, which were connected to each other by TIG, MAG methods and the coated electrode. The main aim of the research was to determine selected mechanical properties in particular hardness and strength of inguinal joints and then, based on the tests carried out, the best methods were selected.
\end{abstract}

Keywords: Welding, aerospace components, TIG, MAG, coated electrode.

Type of the work: Research Paper

\section{INTRODUCTION}

Welding of aluminum alloys plays an important role in machine construction as well as repairs of technical structures. It is defined as a process of permanent joining of at least two elements. Aluminum alloys are characterized by excessive corrosion and chemical resistance and their relatively low specific gravity, which plays a major role in the selection of the structural material. Therefore, aluminum alloys are mainly used in aviation, but also in engineering, automotive, etc. as load-bearing elements or structural elements of flying objects.

During the joining process, it is necessary to pay attention to it's basic conditions such as: durability of the weld, relatively low cost of producing the joint and fulfil its specific function. An important aspect is also the service life of the welded structure its strength, which mainly depends on the type of load and temperature at which the structural element works. On this basis, a number of non-destructive tests have been introduced in order to detect internal defects in joints, so that the service life of a given object is as long as possible. 
Hardness tests: Hardness is defined as the resistance of a material to plastic deformation under load, which is caused by a press-in indenter of a specific shape. These tests are performed using the methods: of Brinell, Vickers, Rockwell based on PN-EN ISO 6507-1:2007 standards. Based on the literature review, the Vickers hardness test method, which is most suitable for welded joints, was chosen.

\section{Description of the Hardness tester}

The tests were carried out using a hardness tester (Fig. 1).

The main parameters of the hardness tester are:

- Maximum load of $2452 \mathrm{~N}$ of the hardness meter HPO -250.

- Accuracy of measurement 0-1.6 mm.

- Mains voltage of $220 \mathrm{~V}$.

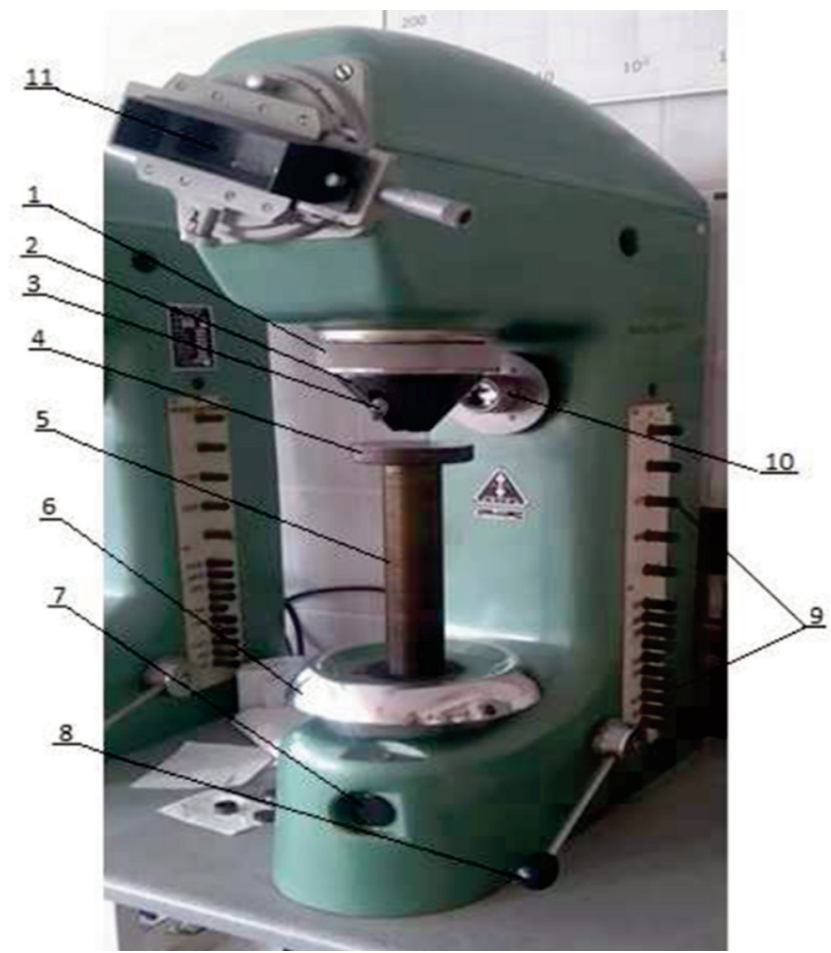

Fig. 1. Hardness tester $\mathrm{HPO}-250$.

1 - phase adjustment nut; 2 - blade; 3 - camera indenter; 4 - table;

5 - lifting screw; 6 - eye manual tightening; 7 - load switch; 8 - load lever;

9 - load values; 10 - lamp projection; 11 - measuring.

\section{RESULTS AND ANALYSIS OF STUDIES}

Force $F$ acted on the indenter for 15 seconds. The hardness measurement was carried out at room temperature of $18^{\circ} \mathrm{C}$, which is within the recommended range otable rigid base and the samples were also protected against movement. The test stand was secured to avoid vibrations and shocks in order to achieve greater reliability. By pressing a button, the indenter was automatically set to a lateral position, then the load range of $294 \mathrm{~N}$ was selected. A view of the samples after hardness testing is shown below. 


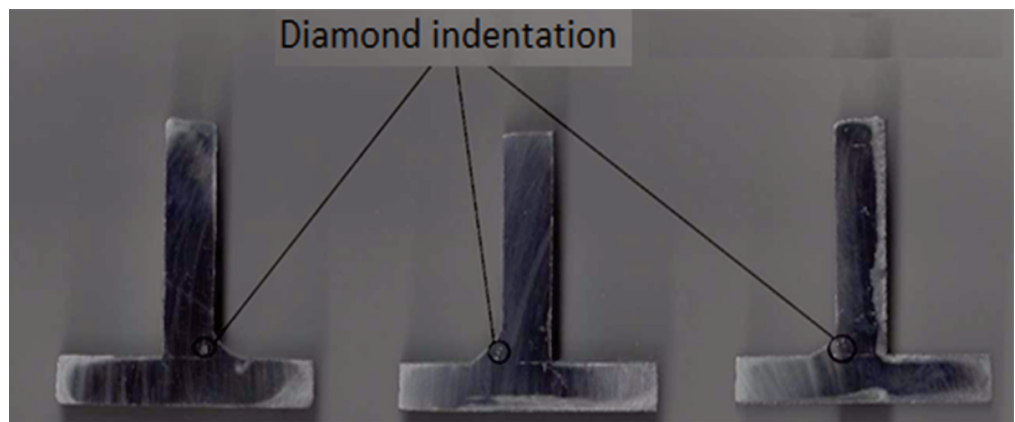

Fig. 2. Sample cross-section after hardness testing MAG method.

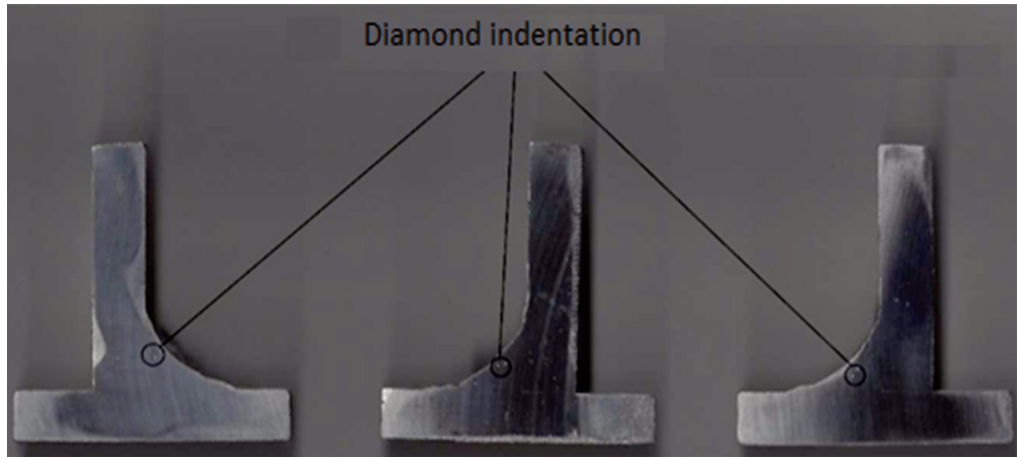

Fig. 3. Joint cross-section after hardness testing TIG method.

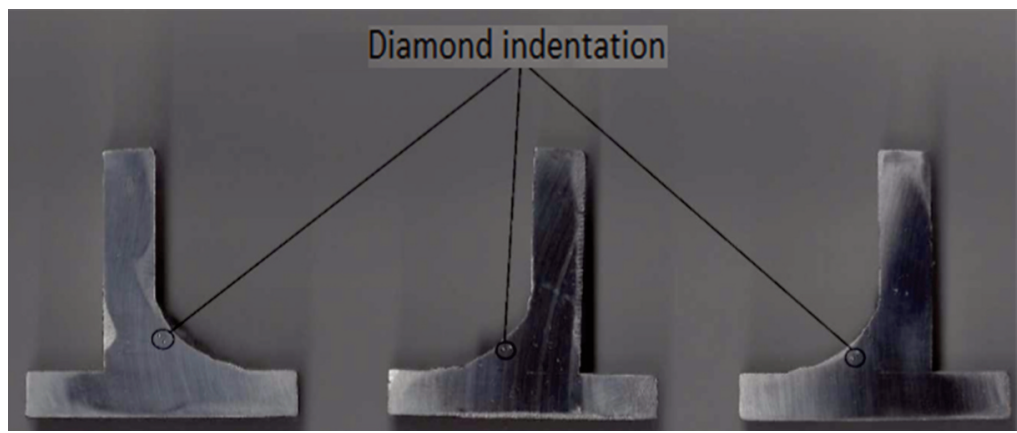

Fig. 4. Joint cross-section after hardness tests with the coated electrode.

After the imprints were made, their diagonals were measured and then averaged, obtaining the value $d$ using the formula (1):

$$
H V=0,189 \frac{F}{d^{2}}
$$

Sample calculations:

Hardness of the sample $H V=0.189 \frac{294}{0,552^{2}}=182,36 \approx 183$. 
Tab.1. Comparison of hardness of MAG, TIG and coated electrode methods.

\begin{tabular}{|c|c|c|c|c|c|c|}
\hline Welding methods & & MAG & & TIG & & d electrode \\
\hline \multirow{3}{*}{$\begin{array}{l}\text { Samples numer } \\
\text { and Hardness }\end{array}$} & 1 & 0.552 & 8 & 0.550 & 4 & 0.562 \\
\hline & 2 & 0.552 & 9 & 0.550 & 5 & 0.562 \\
\hline & 3 & 0.552 & 10 & 0.550 & 6 & 0.562 \\
\hline HV & & 183 & & 171 & & 184 \\
\hline HRC & & 18.3 & & 17.1 & & 18.4 \\
\hline
\end{tabular}

\section{FLEXURAL STRENGTH TESTING OF JOINTS}

Bending strength tests of welded joints were performed on INSTRON 1500 HDX press.

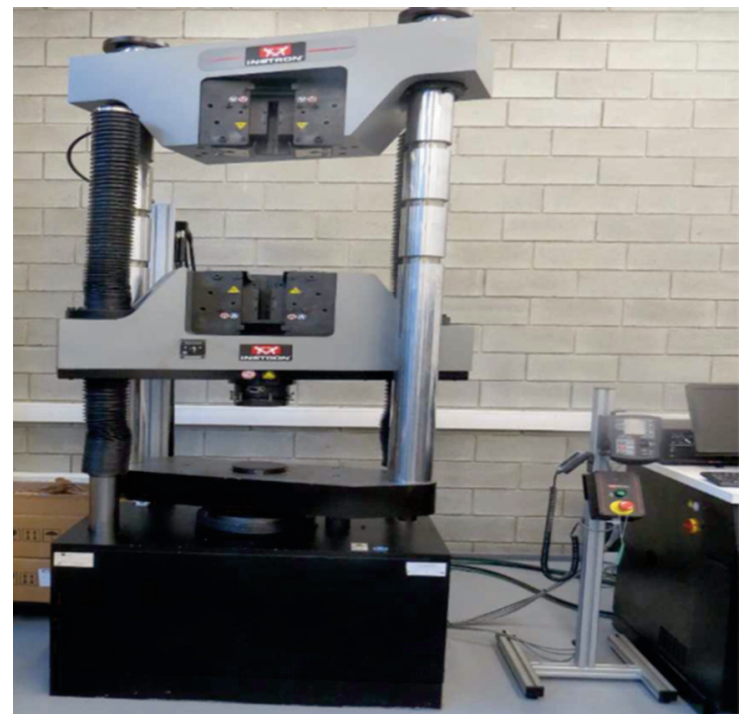

Fig. 5. INSTRON 1500 HDX press.

The INSTRON 1500 HDX press stands out:

- load capacity up to $1500 \mathrm{kN}$;

- maximum test speed of $14 \mathrm{~mm} / \mathrm{min}$;

- actuator stroke $305 \mathrm{~mm}$;

- crossbar speed adjustment $305 \mathrm{~mm} / \mathrm{min}$;

- horizontal opening $762 \mathrm{~mm}$;

- compression size $812 \times 452 \mathrm{~mm}$. 


\section{CONDUCTING AND ANALYSING STRENGTH TESTS}

In order to perform bending strength tests of the joints, a grip and a punch were designed for the specimens due to their small overall dimensions. After the welding process, the stamp and the handle were cleaned and painting (Fig. 6a and 6b) with a pneumatic gun, at 6 bar pressure.

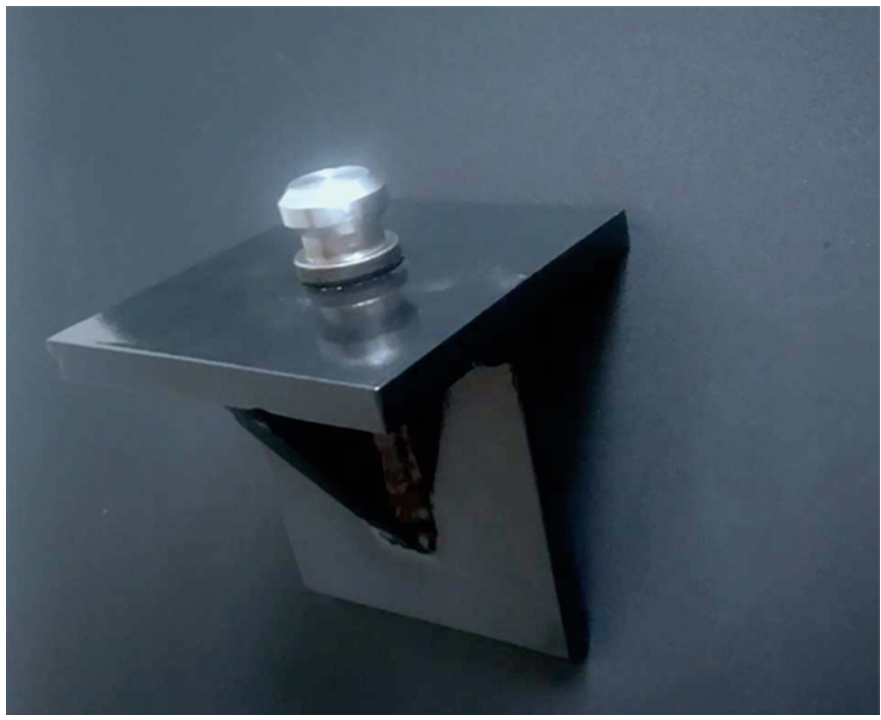

Fig. 6a. Phisical realization of the designed stamp.

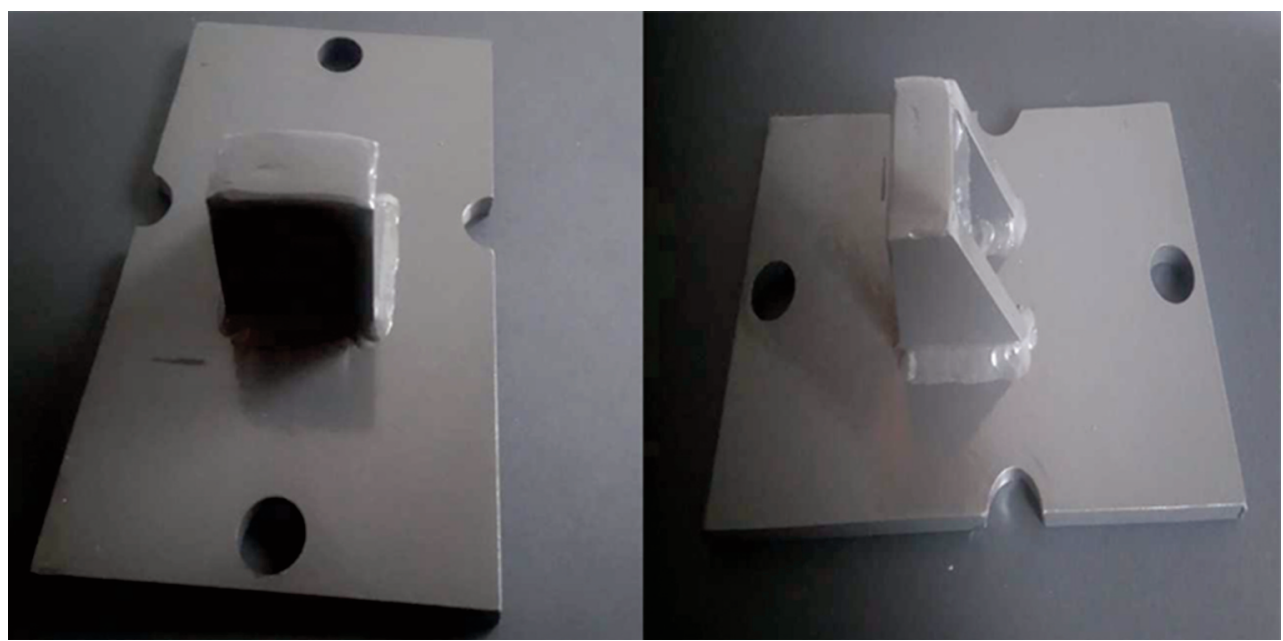

Fig. 6b. Stamp based on the design.

The stamp and the handle were then attached to the INSTRON press.

The results and analysis are presented below: 


\section{Load force graph as a function of displacement}

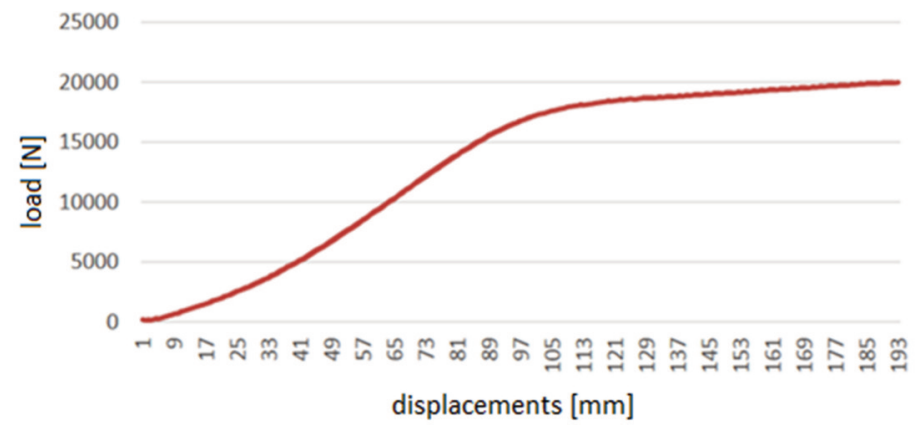

Fig. 7. Loading force as a function of the movement.

\section{Load force graph as a function of displacement}

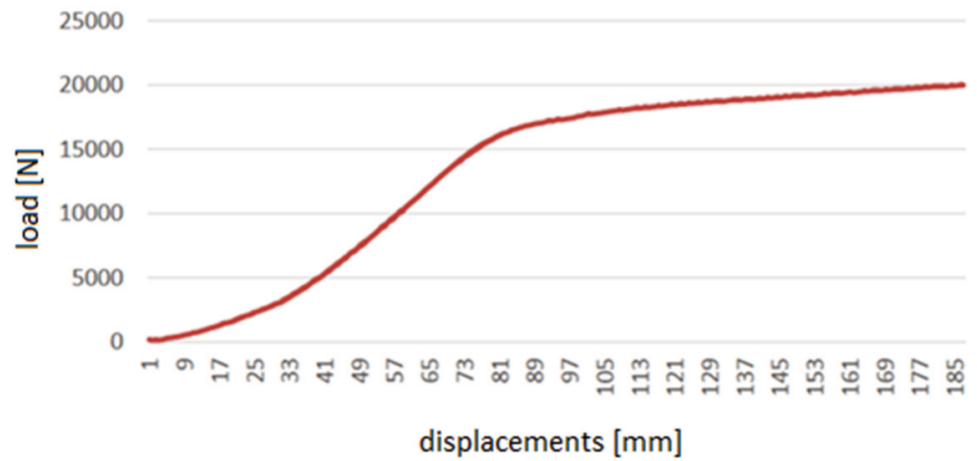

Fig. 8. Loading force as a function of the movement.

\section{Load force graph as a function of displacement}

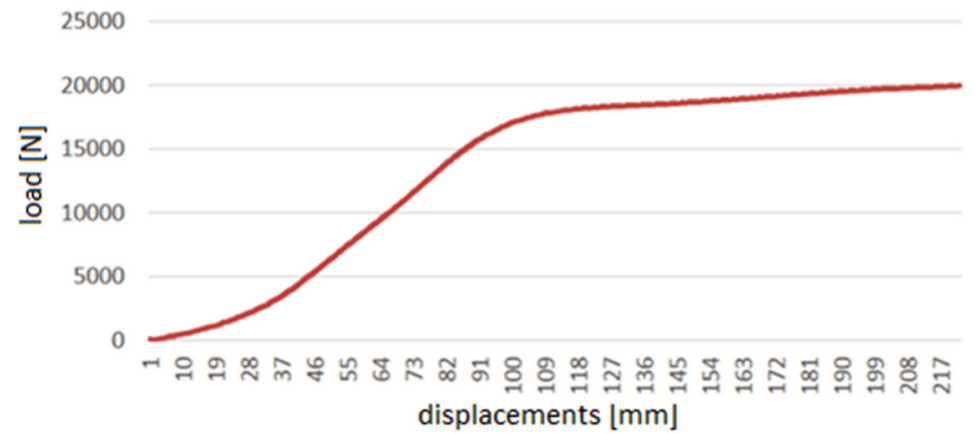

Fig. 9. Loading force as a function of the movement. 
During the bending strength test of the MAG bonded specimens, changes in the binder structure can be observed. At the beginning of the process, the graphs show the loads in the elastic range, while as the load increases, the plasticizing value of the samples increases. This leads to breakage. In the first specimen, using a load of $17.277 \mathrm{kN}$ causes plasticization. The second sample reaches a yield point of $16.996 \mathrm{kN}$ and the third sample of $17.223 \mathrm{kN}$. Small differences show a similar distribution of the binder thickness between the elements to be joined.

\section{Load force graph as a function of displacement}

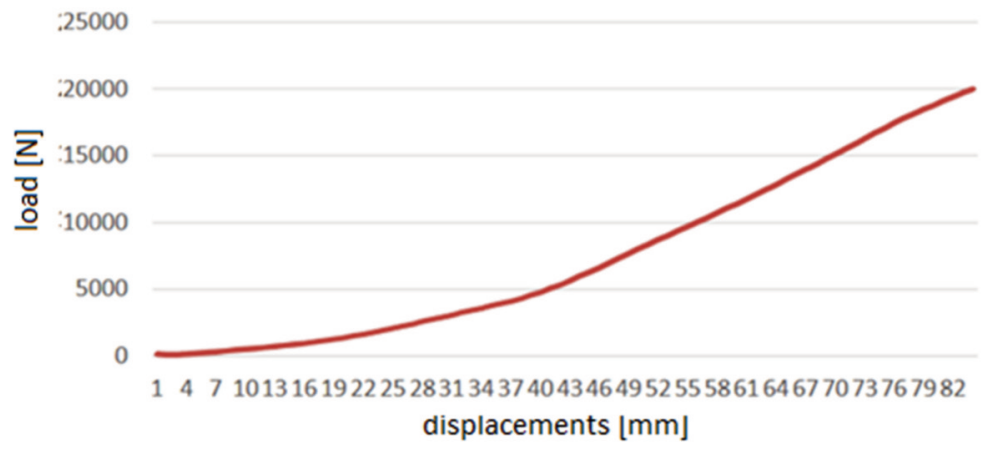

Fig. 10. Loading force as a function of the movement.

\section{Load force graph as a function of displacement}

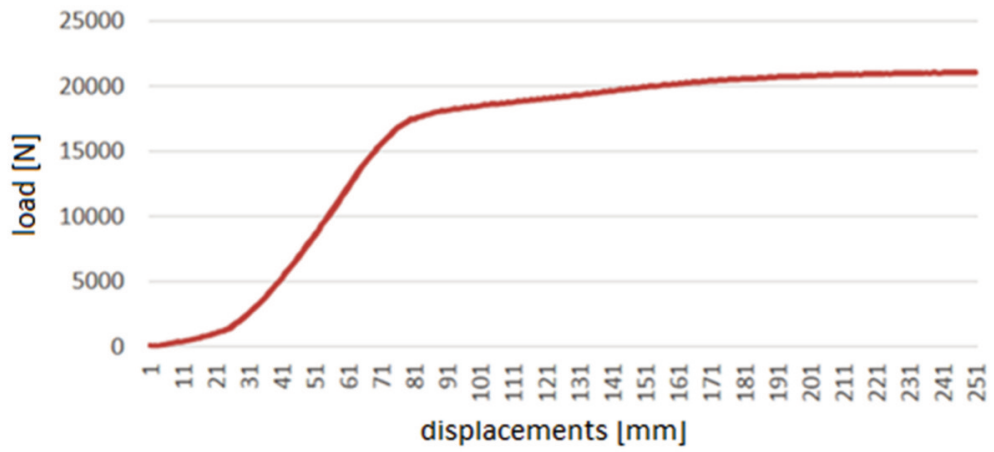

Fig. 11. Loading force as a function of the movement. 


\section{Load force graph as a function of displacement}

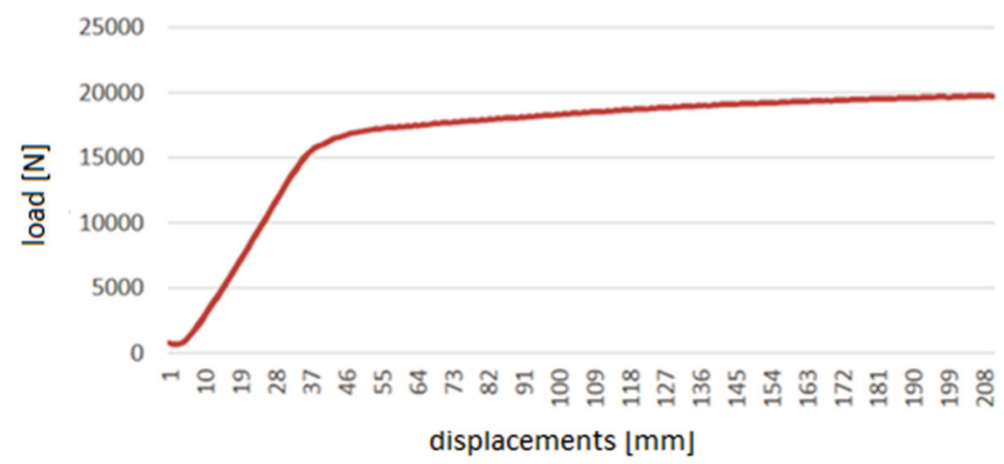

Fig. 12. Loading force as a function of the movement.

Bending strength tests of samples connected by means of a wrapped electrode shows better strength properties. This can be seen from the graphs above. In the fourth sample, the load force used is the highest and is as high as $20 \mathrm{kN}$, with this value exceeding the yield point. If further loading is used, the specimen will rupture. In the fifth sample, the force at which the binder structure changes is $17.591 \mathrm{kN}$ and in the sixth sample $16.627 \mathrm{kN}$. The fluctuations of the applied load are relatively high. This is due to the uneven distribution of the binder.

\section{Load force graph as a function of displacement}

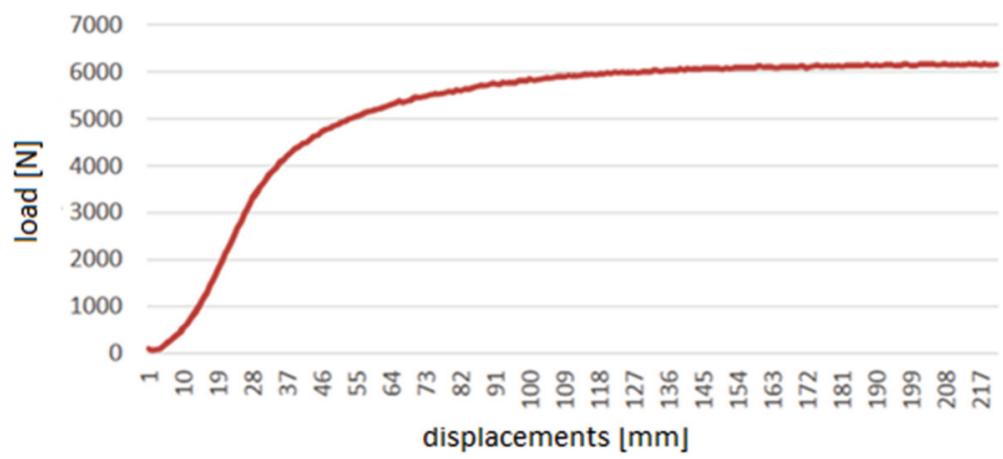

Fig. 13. Loading force as a function of the movement. 


\section{Load force graph as a function of displacement}

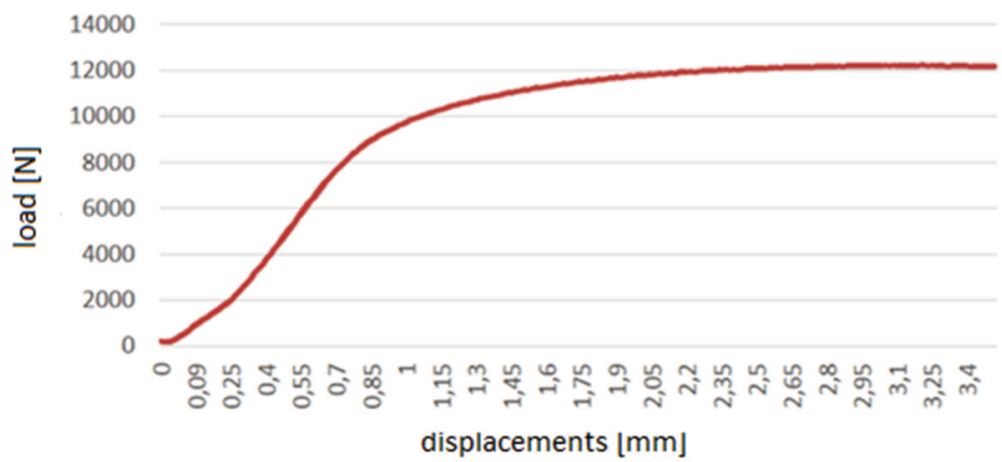

Fig. 14. Loading force as a function of the movement.

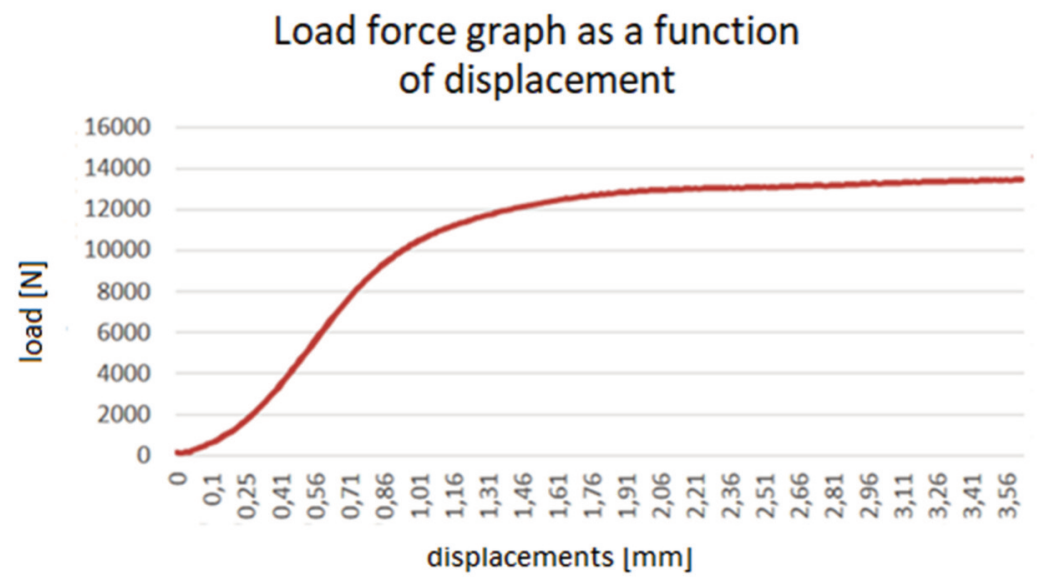

Fig. 15. Loading force course as a function of the movement.

The strength of the welds made with TIG method is the lowest. Only $4.215 \mathrm{KN}$ (eighth sample) is sufficient to exceed the yield point. In the case of the ninth sample, the strength value is higher at 9.758 and in the case of the tenth sample at $11.106 \mathrm{kN}$. Such large differences in the loading force result from the unevenness of the dimensions of the combined elements. The eighth sample had the smallest width, so a small force caused deformation. 
Strength calculations for fillet joints The first step in the strength calculations is to show the bending moment $\left(M_{g}\right)$ during which the samples are destroyed. The $M_{g}$ calculations are shown in the table below:

Tab. 2. Comparison of welding methods.

\begin{tabular}{|c|c|c|c|c|}
\hline Welding & $\begin{array}{c}\text { Sample } \\
\text { numbers }\end{array}$ & Force $\mathrm{P}[\mathrm{kN}]$ & $\begin{array}{l}\text { Length of arm } \\
\text { on which the } \\
\text { force acts [mm] }\end{array}$ & $\begin{array}{c}\text { Bending moment } \\
{[\mathrm{kNmm}]}\end{array}$ \\
\hline \multirow[t]{3}{*}{ TIG } & 8 & $P_{8}=4.215$ & \multirow{3}{*}{19.6} & $M_{g 8}=82.6$ \\
\hline & 9 & $P_{9}=9.758$ & & $M_{g 9}=191.3$ \\
\hline & 10 & $P_{10}=11.106$ & & $M_{g 10}=217.7$ \\
\hline \multirow[t]{3}{*}{ MAG } & 1 & $P_{1}=17.277$ & \multirow{3}{*}{19.4} & $M_{g 1}=335.2$ \\
\hline & 2 & $P_{2}=16.996$ & & $M_{g 2}=329.7$ \\
\hline & 3 & $P_{3}=17.223$ & & $M_{g 3}=334.1$ \\
\hline \multirow{3}{*}{$\begin{array}{l}\text { Wrapped } \\
\text { electrode }\end{array}$} & 4 & $P_{4}=20$ & \multirow{3}{*}{19.4} & $M_{g 4}=388$ \\
\hline & 5 & $P_{5}=17.591$ & & $M_{g 5}=341.3$ \\
\hline & 6 & $P_{6}=16.627$ & & $M_{g 6}=322.6$ \\
\hline
\end{tabular}

\section{SUMMARY}

The tests performed allowed us to determine which samples were made correctly and which have internal defects like and external. The following conclusions can be drawn from the research:

- all samples made with the TIG, MAG and coated electrode methods had a sufficiently high strength, their small differences do not affect the choice of method for structural joints;

- bending of small samples is possible thanks to the design of the appropriate punch and handle;

- the sharpened end of the punch allowed to precisely indicate and subsequently measure the place of the load acting;

- an important parameter in the bending of specimens is the loading force, which makes it possible to determine at what loads the joints should not be used.

\section{Acknowledgement}

"This publication was realized with support of Operational Program Integrated Infrastructure 20142020 of the project: Research and development of the usability of autonomous aerial drones in the fight against the pandemic caused by COVID-19, code ITMS 313010ATR9, co-financed by the European Regional Development Fund”. 


\title{
REFERENCES
}

[1] Lusiak, T., Novak, A., Bugaj, M., Madlenak, R., 2020, "Assessment of impact of aerodynamic loads on the stability and control of the gyrocopter model". Communications - Scientific Letters of the University of Zilina, 22(4), pp. 63-69. 10.26552/com.C.2020.4.63-6.

[2] Catlos, M., Kurdel, P., Sedlakova, A. N., Labun, J., Ceskovic, M., 2018, "Continual monitoring of precision of aerial transport objects". Paper presented at the NTAD 2018 - 13th International Scientific Conference - New Trends in Aviation Development, Proceedings, pp. 76-81. 10.1109/NTAD.2018.8551683.

[3] Kurdel, P., Sedlácková, A. N.; Labun, J., 2019, "UAV flight safety close to the mountain massif”. Paper presented at the Transportation Research Procedia, 43, pp. 319-327. 10.1016/j.trpro.2019.12.04

[4] Sedláčková, A. N., Kurdel, P.; Labun, J., 2020, "Simulation of unmanned aircraft vehicle flight precision”. Paper presented at the Transportation Research Procedia, 44, pp. 313-320. 10.1016/j.trpro.2020.02.03.

[5] Čerňan, J., Rodziňák, D., Semrád, K., Truchlý, M., 2015, “The tribological properties of the coated sintered material”. Acta Metallurgica Slovaca, 21(1), pp. 44-52. 10.12776/ams.v21i1.467.

[6] Fördös, P., Čerňan, J. 2020. "Analysis of the impact of hard pvd coatings on the abrasion resistance of the compressor blades". Advances in Military Technology, 15(1), pp. 85-95. 10.3849/aimt.01333.

[7] Fozo, L., Čerňan, J., Cúttová, M., Ratkovská, K., Adamčík, F., 2017, "Effect of TBC on heat transfer into nickel based refractory alloy". Paper presented at the SAMI 2017 - IEEE 15th International Symposium on Applied Machine Intelligence and Informatics, Proceedings, pp. 435438. 10.1109/SAMI.2017.7880348.

\section{BADANIA WYBRANYCH WŁAŚCIWOŚCI MECHANICZNYCH POŁĄCZEŃ SPAWANYCH W WIROPŁATACH}

\begin{abstract}
Abstrakt
W niniejszym artykule przedstawiono eksperymentalne zastosowanie różnych sposobów łączenia pachwinowego elementów statku powietrznego metodą TIG (Tungsten Inert Gas), MAG (Metal Active Gas) oraz elektrodą otuloną łukową. Przedmiotem badań były próbki elementów wiropłatów, które połączono ze sobą metodami TIG, MAG oraz elektrodą otuloną. Głównym celem badań było określenie wybranych właściwości mechanicznych w szczególności twardości i wytrzymałości spawów pachwinowych, a następnie na podstawie przeprowa-dzonych badań wybrano najlepsze metody.
\end{abstract}

Słowa kluczowe: Spawanie, komponenty lotnicze, TIG, MAG, elektroda otulona. 